\title{
English Pedagogy for Student with Emotional and Behavioral Disorders In An Inclusive School
}

\author{
Desty Meidina Andhini ${ }^{*}$, Laela Hikmah Nurbatra ${ }^{2}$ \\ a),b) Universitas Muhammadiyah Malang, Jl. Raya Tlogomas no 246 Malang, Jawa Timur, Indonesia. \\ *Corresponding Author \\ e-mail: nurbatra@gmail.com
}

\begin{abstract}
Inclusive school is a public school that the student with special needs can be educated together with normal students. Expanding the potential that they have through the appropriate teaching strategies is crucial to implement, especially for the student with EBD. The student with EBD is a student that has aggressive behavior and substantial negative influence in the learning process. In accordance to that, the researcher wants to investigate (1) the teaching strategies used by the English teacher for the student with Emotional and Behavioral Disorders (EBD), (2) the implementation of teaching strategies used by the English teacher for the student with Emotional and Behavioral Disorders (EBD). Using qualitative method, the research involves one English teacher of SD Satu Atap Sumbersari 1 Malang Inclusive School. The instruments used were observation and interview. The current research revealed that there were three strategies used by the English teacher at SD Satu Atap Sumbersari 1 Malang Inclusive School. First, the teacher shows the interest towards students' progress through communication to the student with EBD. Second, giving the student an understanding to have control for everything occurring in their life by giving the student with EBD punishment when break the rules. Third, conducting class activities relevant to students' interest with alternative activities made by the English teacher.
\end{abstract}

Keyword: Teaching English, Strategy, Student with EBD.

\section{INTRODUCTION}

Inclusive school is a public school that also caters students with special needs by implementing an inclusive education system. Through inclusive education, it is expected that the students with special needs can be educated together with normal students. It means that there is no gap between them, which can expand the potential that they have (Marti, 2012). It is supported by the Law No. 23 of 2002 on Child Protection, especially Article 51 which said, "Children with physical or mental disabilities are given an equal opportunity in obtaining an education" (Garnida, 2015).

Iswari (2007:2) as cited in Marti (2012), states that students with special needs have disorders of physical, mental, emotion, or a combination from those disorders. Students with special needs are students who need an education which appropriate to the individual needs, because each student has different background of life, development, and the level of education service. Students who are in growth period of disappointing experience will bring up the problem of adjustment disorder (Atmodiwirjo 2008 as cited in Anggaswari and Budisetyani, 2016). One of its forms is Emotional and Behavioral Disorders.

The student with Emotional and Behavioral (EBD) are students who have difficulties in adapting to the environment of the class (Somantri, 2007). The symptoms of emotional and behavioral disorders are divided into two types, namely externalizing behavior and internalizing behavior. Based on Hallahan \& Kauffman (2006) as cited in Ilahi (2013), externalizing behavior has direct (aggressive behavior) and indirect effects (stealing) toward friends and himself. 
Website : http://ejournal.umm.ac.id/index.php/ipa | E-mail : jpa@umm.ac.id

Jurnal Perempuan dan Anak (JPA), Vol. 1 No. 1, Februari 2021, pp. 15-24

ISSN: 2442-2614 print | 2716-3253 online

Universitas Muhammadiyah Malang

Meanwhile, internalizing behavior is a disorder in the form of depression or severe anxiety, withdraws from social interaction, and excessive mood swings. So, students with EBD have substantial negative influence in the learning activities (Ormrod, 2008).

Students with Emotional and Behavioral (EBD) are students identified as students with special needs, because they have various problems such as antisocial behavior, an inability to establish relationships with adults and peers, and negative impact on achievement than they are similar (Ormrod, 2003). Therefore, special educational services should be given to them, because some students with EBD are caused by two factors. First, care treatment factor in environment such as inappropriate care treatment towards students and life pressure in family. Second, there is a factor in school like disturbing their achievement and relation with friends because their emotion and behavior are different (Ormrod, 2009).

Symptoms of emotional and behavioral disorders are usually divided into two types, namely externalizing behavior and internalizing behavior (Ilahi, 2013). Externalizing behaviors have direct or indirect impacts with the others, such as aggressive, disobedience, stealing, and lack of selfcontrol. Internalizing behavior affects the students with anxiety, depression, and antisocial (Hallahan \& Kauffman, 1988; Eggen \& Kauchak, 1997 as cited in Mahabbati, 2006). Furthermore, Anderson (2012) said that the symptoms divided into three groups. Those are (1) externalizing behavior, (2) internalizing behavior, and (3) low incidence. The externalizing and internalizing behaviors are similar to Hallahan et al. above. Meanwhile, low incidence is infrequent disorder that if it happens will cause hard situation.

In social interaction, the student with EBD plays with friends but more likely disturbing them (Ormrod, 2009). In part of behavioral, the student with EBD does aggressive behavior toward teacher or friends in the learning process (Thompson, 2010). For example, hitting, fighting, mocking, shouting, refusing to obey other people's requests including teacher and friends (Mahabbati, 2006). Life pressure; parents' divorced, alcoholic family, and living in criminal environment are the cause of student with EBD (Santrock, 2009). In communication, the student with EBD is able to do nonverbal social interaction such as eye contact, having expression to express his feeling, and nonchalant (Surna, et. al, 2014).

In the learning process, the teacher gives more attention to the various strategies in order to control the class. A strategy is a pattern that is planned and determined to do an activity (Majid, 2016). A strategy that applied in learning activity is called teaching strategy. Teaching strategy is learning system in the form of activity framework (Majid, 2016). It contains a plan, method, or series of activities to achieve the goal (J.R David, 1976 as cited in Sanjaya).

There are different views in defining teaching strategy. Based on Majid (2016), teaching strategy is a plan of activities in learning that are structured to achieve the goal of learning. In addition, Kozma in Sanjaya (2007) said, teaching strategy can be translated as each activity that selected to help the students to reach certain learning objectives. The last but not least, teaching strategy is an action plan (series of activities) including the use of methods and the use of various resources in learning (Sanjaya, 2006). In my perspective, the term of teaching strategy is teaching plans and tactics that teacher utilizes and implements in the class, while this strategy can change based on the learning process occurs in the class for the sake of achieving learning objectives.

Ormrod (2009) states that the strategies for student with EBD to keep being motivated doing assignments and to keep achieving in the learning process, because these kinds of student find the difficulties in academic and cognitive process, as follows: 
Website : http://ejournal.umm.ac.id/index.php/ipa | E-mail : jpa@umm.ac.id

Jurnal Perempuan dan Anak (JPA), Vol. 1 No. 1, Februari 2021, pp. 15-24

ISSN: 2442-2614 print | 2716-3253 online

Universitas Muhammadiyah Malang

\subsection{One on One Communication towards Students' Progress}

Teacher becomes good listener when the students tell their problems and give attention and solution when they look under pressure or worried (Ormrod, 2009). It is because of the student with EBD occur stressful, therefore it's a necessary for them a humanist communication with the teacher (Ormrod, 2011 as cited in Surna, et. al, 2014). The teacher also gives praise towards students who did a good behavior (Simonsen et al., 2008 as cited in Bak, 2013) because the teachers who care towards students is the first good step as stated by Diamond (1991 as cited in Ormrod, 2009) and encourage students to repeat a good behavior in their future (Bak, 2013).

\subsection{Giving Direct Commands to the Student}

Students with EBD mostly act inappropriately and are against; then the teacher has to create the situation where the students understand that they are in control of what they experience by adjusting to the class (Ormrod, 2009). Ormrod (2011, as cited in Surna, et. al, 2014) also added not only adjusting to the class, but also giving attention totally (seriously) to students with EBD. This is because inappropriately behavior to them disrupts the learning process. Thus, the teacher can give an understanding of what they done is contrary to the existing rules, so that students with EBD capable to regulate and determine the behavior that should be done (Ormrod (2011, as cited in Surna, et. al, 2014).

\subsection{Conducting Class Activities Relevant to Students' Interest}

When the activity is appropriate with the students' interest, it makes the students more understand about the activity. So, their higher curiosity gains more knowledge and interest during learning process (Blumenfeld et. al., 2006; Hidi \& Mc Laren, 1990; Tobias 1994 as cited in Ormrod, 2009). In addition, according to Bak (2013), maintaining motivation is also needed through SelfRegulated Strategy Development (SRSD). This case occurs because it can emerge frustration and inappropriate behavior at high level. So, using SRSD possibly allows the students with EBD to experience an instructional step that maintains motivation and allow them to deal with frustration properly (Bak, 2013). It because the struggle that the students with EBD find can be fixed and maintained during the learning process (Mason \& Shriner, 2008 as cited in Bak, 2013) and it will produce positive effects on their academic outcomes (Mooney et al., 2005 as cited in Bak, 2013).

\subsection{Paying Attention to Students who Plan to Commit Suicide}

Students with EBD (Emotional and Behavioral Disorders) have suicidal tendencies especially in girls, because they grow with somatic and psychiatric disorders (Pradnyawati \& Ardjana, 2015). So, the teacher must pay attention to the sign of students who want to end their lives. For example: (1) students who withdraw themselves from socializing, (2) students who ignore their appearance, (3) students who often talk terrible things and about death, and (4) students who often change moods immediately (Ormrod, 2009). Most students who experience these signs are students who are very depressed. For this reason, the teacher has a role to help students with EBD (Emotional and Behavioral Disorders) behave in a more appropriate manner/attitude by making students with EBD do more interact effectively with others and creating a conducive classroom environment in the learning process (Ormrod, 2009). 
Website : http://ejournal.umm.ac.id/index.php/ipa | E-mail : jpa@umm.ac.id

Jurnal Perempuan dan Anak (JPA), Vol. 1 No. 1, Februari 2021, pp. 15-24

ISSN: 2442-2614 print | 2716-3253 online

Universitas Muhammadiyah Malang

In the preliminary study, SD Satu Atap Sumbersari 1 Malang Inclusive School has one student with special needs in each class when the researcher did survey. There is student with EBD (Emotional and Behavioral Disorders) in the fifth class. The teacher mentioned that she has to use various teaching strategies in teaching English with this student during the learning process. For instance, when disturbing his friend, the teacher needed to turn the student's attention to other things such as doing exercises, asking the student to write his answer on the whiteboard when he looks angry, and saying something to praise him when he did something wrong. Those are problems that teacher face in Inclusive School. That is why teacher should be able to manage learning process through teaching strategy.

There are only few research that focused on teaching strategies for students with EBD. Based on the reason above, the writer is interested in conducting this research with expectation to add references for teachers to teach students with EBD. Also, they have comprehensive understanding on various teaching strategies for the students with Emotional and Behavioral Disorders.

Based on the background above, the research problems are formulated as follows :

1. What the strategies are used by the teacher in teaching English for the student with Emotional and Behavioral Disorders at SD Satu Atap Sumbersari 1 Malang Inclusive School?

2. How does the teacher implement the strategies in teaching English for the student with Emotional and Behavioral Disorders at SD Satu Atap Sumbersari 1 Malang Inclusive School?

This research is aimed for English teachers so they can get insights about the teaching strategies for the student with Emotional and Behavioral Disorders (EBD). Moreover, the result of this research is also expected to give significance to the student with Emotional and Behavioral Disorders (EBD). Through the acceptable implementation of teaching strategies, the Emotional and Behavioral Disorders student are expected to understand the lesson easily.

\section{RESEARCH METHOD}

In this current study, the researcher used qualitative research to describe the implementation of the teaching strategies used by the English teacher in teaching English for the student with Emotional and Behavioral Disorders at SD Satu Atap Sumbersari 1 Malang Inclusive School. Qualitative research can be used as a means to explore and deepen our understanding about certain phenomena (Creswell, 2009). The subject of this study was the English teacher who taught the fifth grade male student with Emotional and Behavioral Disorders at SD Satu Atap Sumbersari 1 Malang Inclusive School.

In this study, the researcher used observation and interview as a means to collect the data of teaching strategies for the student with Emotional and Behavioral Disorders (EBD) used by the English teacher in inclusive school. This research applied non-participant observation due to in this research the researcher did not participate directly in the teaching and learning activity. In this case, the researcher only acted as an observer in which the researcher just need to paid attention and observed the way the English teacher taught the student with EBD in the class. Based on Williams (2014), non-participant observation means the observer did not participate directly in the phenomena or situation that being observed but rather "sit on the sidelines", and watch. Field notes used by the researcher when did the observation. According to Ary et al (2010), the field notes or brief notes are used to complete the data from the interview during observations in class. Descriptive and reflective parts are the components of the common method to collect the data with field notes. Descriptive part is a full explanation of interpersonal relationships, settings, and incident reports. Reflective part is personal impression about data analysis toward records of events, ethical issues, 
Website : http://ejournal.umm.ac.id/index.php/ipa | E-mail : jpa@umm.ac.id

Jurnal Perempuan dan Anak (JPA), Vol. 1 No. 1, Februari 2021, pp. 15-24

ISSN: 2442-2614 print | 2716-3253 online

Universitas Muhammadiyah Malang

speculations, and research methods, which include picture notes, video and audio recordings (Ary et al., 2010). On the field notes, the researcher described what are teaching strategies that the English teacher used for the student with EBD, and also the implementation in the class. The researcher used table to manage the field notes observation.

The researcher used semi structured interview to collect the data. Interview was a qualitative method used to collect the data from people related to the opinions, beliefs, and feelings of phenomena on their own words (Ary et al., 2010). Semi structured interview was selected due to the researcher had prepared or scheduled the questions which will be asked to the research subject and this interview does not only focus on the questions that have been listed but provides an open opportunity to discuss other topics in more detail than the list.

\subsection{Procedure}

In gathering the data, the researcher takes five steps as follows :

1. The researcher prepared the field note for observation.

2. The researcher observed the classroom activity during teaching and learning process to know what kind of teaching strategies used and how the teacher implements it.

3. The researcher prepared interview guideline for the interview.

4. The researcher did the interview with the English teacher related to the teaching strategies which was used by the teacher.

5. The researcher transcribed the interview.

\subsection{Data Analysis}

When gathering the data has been done, the researcher then analyzed it in the following steps :

1. Identifying the teaching strategies that used by the teacher in the class.

2. Analyzing the teaching strategies found by the researcher.

3. Transcribing the data from the interview session.

4. Identifying the teaching strategies that used by the teacher and how the teacher implements it.

5. Analyzing the teaching strategies that used by the teacher and how the teacher implements it.

6. Drawing conclusions.

\subsection{Findings}

In the finding, the researcher presents the data from interview and observation. Furthermore, in the discussion, the researcher describes the teaching strategies used by the English teacher and the way to implement the teaching strategies for the student with Emotional and Behavioral Disorders (EBD).

\subsection{Teaching Strategies Used by the English Teacher for the Student with EBD and the Implementation}

The research data were obtained from the observation at English class and from the interview. The first observation and interview were done on 29 March 2018 and the second were done on 15 November 2018. The findings on the teaching strategies and the way to implement the teaching strategies used by the English teacher for the student with EBD are as follows :

\subsubsection{One on One Communication towards Students' Progress}

Based on second observation, the teacher did not only convey the lessons in class, but also share stories about the problems, difficulties, and doubts that the student with EBD has, either personal life or academic matters. This way was done through communication with the student, for instances, when the 
Website : http://ejournal.umm.ac.id/index.php/ipa | E-mail : jpa@umm.ac.id

Jurnal Perempuan dan Anak (JPA), Vol. 1 No. 1, Februari 2021, pp. 15-24

ISSN: 2442-2614 print | 2716-3253 online

Universitas Muhammadiyah Malang

student with EBD felt that the explanation from the teacher was not in accordance with students' understanding, the teacher was able to link the students' opinions with him to avoid misunderstanding. Other situations that showed the students' progress also occurred when the teacher started the lesson with a new topic. The teacher made the student with EBD really focused and curious about the explanation because the student with EBD had never known before. From that situation, the teacher asked the student with EBD to re-explain with his own sentences about the topic. It was proven by the interview section with the teacher. The English teacher said,

"When I explained what the definition was then he disagreed with me, he immediately questioned me why it didn't work by this way. To overcome this misconception, I re-explained to him in front of all students with similar language with my earlier explanation and added with his opinion". (Appendix)

"Usually, he always paid attention and was interested when the new topic had never been known. So, when I saw this, I tested his understanding by asking him to re-explain with his own language". (Appendix).

\subsubsection{Giving Direct Commands to the Student}

Based on the second observation, before the lesson started, the student with EBD played in his friend's table and took a walked around in class. When the bell rang and the teacher was in the class to start the lesson, all of the students run to go back to their seats excepts the student with EBD. At that time, the teacher came and gave an explanation to the student with EBD to sit on his place because the lesson would begin. The learning process was going very well until the teacher asked all of the students to do examination, then the student with EBD started to talk to his friend who focuses on doing examination. For this situation, the teacher gave him two options; first, the student with EBD could leave the class after collecting the test answer sheet or the student with EBD keep quite during the examination. In order to keep the learning process effectively, it is important to have collection of strategies such as assignments that the student with EBD had to do and topics that the student with EBD had to read. It was proven by the interview section with the teacher. The English teacher said,

"I told to him that if you do that, it would disturb your other friends who are working on the exam. If you do not like being in class, you can leave the class after collecting your test answer sheet or stay but keep quite".

"I usually give assignment to work on the white board so as not to disturb his friends. After that, I said, "after this sit down, no need to go anywhere or you can leave the class".

"The assignment must be done because I will give score".

“...You can immediately work on a few questions or read the next topic...”.

\subsubsection{Conducting Class Activities Relevant to the Students' Interest}

The result of the analysis showed that the teacher assured all of the students to understand the contents of the subject matter. Furthermore, the teacher used the appropriate teaching strategies that suit with student learning style. Specifically, the student with EBD who did not like writing and direct instruction was given alternative activities. This was aimed to prevent him from feeling uninterested on teacher's explanation or disrupting his friends through question and answer session, and the tasks was done on the board. It was proven by the interview section with the teacher. The English teacher said, 
Website : http://ejournal.umm.ac.id/index.php/ipa | E-mail : jpa@umm.ac.id

Jurnal Perempuan dan Anak (JPA), Vol. 1 No. 1, Februari 2021, pp. 15-24

ISSN: 2442-2614 print | 2716-3253 online

Universitas Muhammadiyah Malang

"His name must be called to participate in learning activities, except for one English skill, which is writing. He did not want to be told to write".

"I usually open a question and answer session because he did not like being told or ordered immediately, especially if he is told to come forward to work on the board in a bad mood".

“...He dislikes it when I tell to him to work on the questions in the LKS book and collect them, but he preferred being commanded to move forward to work on some of the questions on board. So, I told him to come forward class often...".

\section{RESULTS and DISCUSSION}

Based on the result of data analysis, SD Satu Atap Sumbersari 1 Malang is one of the inclusive schools that gives opportunities to learn together in the same classroom for the normal students and the students with special needs (Mahabbati, 2010), including the student with EBD. The student with EBD is included in one type of students with special needs with categories students with social or behavioral problems (Ormrod, 2011 as cited in Surna, et. al, 2014). Some of the symptoms of this student are disruptive, having feelings of depression, and having serious difficulties of schoolwork (Anderson, 2012). Therefore, in order to keep being motivated doing assignments and to keep achieving in the learning process, the teacher should apply the teaching strategies for the student with EBD (Ormrod, 2009).

Based on the result of the research findings, teaching strategies used by the English teacher for the student with Emotional and Behavioral Disorders (EBD) in learning English at SD Satu Atap Sumbersari 1 Malang Inclusive School are approaches; one on one communication towards students' progress, giving direct command to the student, and conducting class activities relevant with students' interest. The result of this research was framed in the theory of teaching strategies for the student with EBD by Ormrod (2009) which stated that there were four of teaching strategies used by the English teacher such as one on one communication towards students' progress, giving direct commands to the student, conducting class activities relevant with students' interest, and paying attention to students who plan to commit suicide.

Based on the kinds of teaching strategies according to Ormrod (2009), the first teaching strategy is one on one communication towards students' progress. This strategy has a meaning that the teacher becomes good listener to the students that have problems and gives them attention and solution when they look under pressure or worried (Ormrod, 2009). The statement above was related to this research that the student with EBD would ask the teacher directly when there was teacher's opinion that was not match with his opinion. For this situation, the teacher took an action by giving more detail explanation added with opinion of the student with EBD to avoid misunderstanding. This teaching strategy step can also change the teacher's mindset who have more positive expectations only for high ability students than the students with low abilities (Santrock, 2011). In addition, the researcher found that the student with EBD always looked curious when the teacher explained the new topic on that day. To respond to this, the teacher clarified the students' understanding by explaining with his own sentences. In line with that, Marti (2012) also agreed that the teacher must be able to understand the condition of students who have disabilities in the classroom so they can adapt their lessons and be able to apply their skills in teaching.

The second kind of teaching strategies is giving direct commands to the student. The teacher has to create the situation where the students understand that they are in control of what their experience, because mostly the students with EBD do inappropriately behavior (Ormrod, 2009). The statement above was related to this research because the researcher found that there was a situation where the student with EBD 
Website : http://ejournal.umm.ac.id/index.php/ipa | E-mail : jpa@umm.ac.id

Jurnal Perempuan dan Anak (JPA), Vol. 1 No. 1, Februari 2021, pp. 15-24

ISSN: 2442-2614 print | 2716-3253 online

Universitas Muhammadiyah Malang

could not control himself during the examination and it disturbed his friends. So, the teacher made control the student with EBD and gave options. First, the student with EBD could go out of the class after finishing his examination, or the student with EBD could stay in the class but he kept quiet during the examination in order not to disturb his friends. The teacher can establish clear rules and providing consequences for student behavior (Marzano et. al., (2003) because the high rates of negative behavior in students depends on the high rates of negative teacher practices (Beyda et. al., 2002). During observation, the researcher also recognized that the teacher controlled the student with EBD well in the class by saying that the student needed to go back to his chair, pay attention, complete his assignment on the white board, and to read the next topic on the book. Those strategies have purposes to shape an effective and an efficient learning process that must be maintained (Hasanah, 2015).

The last teaching strategy for the student with EBD is conducting class activities relevant to students' interest (Ormrod, 2009). This strategy is important to use in order to make the student has curiosity and more understanding the lessons deeply, the teacher has to adapt how she is teaching with the way of student's learn (Blumenfeld et. al., 2006; Hidi \& McLaren, 1990; Tobias, 1994 as cited in Ormrod, 2009). It is because teacher instructional behavior might influence the academic failure and problem behavior of the student with EBD (Sutherland, 2008). The statement above was related to this research because the researcher found to avoid those situations happen, the teacher has some alternative activities to learn with EBD student's preference, for example involving the student with EBD to answer questions or giving his opinion on things can make the student with EBD enjoy the learning process. A good relationship between the teacher and the student with EBD is contradict to McDuffe's statement (2008) which said that students with EBD are notorious for their inability to get along with peers and teachers. Furthermore, the researcher also found that after the teacher knew the student with EBD did not like in writing on book, she often asked the student with EBD to come forward for answering some questions on the whiteboard. The more positive interactions that occur between the teacher and the student, the better their relationship will be (Conroy, 2012).

\section{CONCLUSION}

Based on the findings and discussions, there were three teaching strategies used by English teacher at SD Satu Atap Sumbersari 1 Malang Inclusive School. Firstly, making one on one communication towards student's progress. This strategy can be used by the English teacher to make communication with the EBD student in order to avoid misunderstanding and made the student with EBD able to re-explain the material with his own sentences. Secondly, giving direct commands to the student. It can be implemented by tight rules that can be broken by the student with EBD. So, the student with EBD followed the rules or he would get the punishment. The last strategy is conducting class activities relevant to students' interest. The teacher applied this strategy by making alternative activities to make the student with EBD follow the learning process match with the student's like.

\section{REFERENCES}

Anderson, S. R. (2012). Psycho-educational processes as strategies for students presenting with emotional and behavioural disorders. American International Journal of Contemporary Research, 2(7), 25-36.

Anggaswari, A. W. D., \& Budisetyani, W. (2016). Gambaran kebutuhan psikologis pada anak dengan gangguan emosi dan perilaku (tinjauan kualitatif dengan art therapy sebagai metode penggalian data). Jurnal Psikologi Udayana, 3(1), 86-94. 
Website : http://ejournal.umm.ac.id/index.php/ipa | E-mail : jpa@umm.ac.id

Jurnal Perempuan dan Anak (JPA), Vol. 1 No. 1, Februari 2021, pp. 15-24

ISSN: 2442-2614 print | 2716-3253 online

Universitas Muhammadiyah Malang

Ary, D., Jaccobs, L. C., \& Sorensen, C. K. (2010). Introduction to research in education (8th Editio, Vol. Eighth Edi, pp. 1-653). Canada.

Bak, N., \& Asaro-Saddler, K. (2013). Self-regulated strategy development for students with emotional behavioral disorders. Beyond Behavior, 46-53.

Beyda, S. D., Zentall, S. S., \& Ferko, D. J. K. (2002). The relationship between teacher practices and the task-appropriate and social behavior of students with behavioral disorders, 27(3), 236-255.

Conroy, M. A., \& Sutherland, K. S. (2012). Effective teachers for students With emotional/behavioral disorders: active ingredients leading to positive teacher and student outcomes. Beyond Behavior, 19.

Creswell, J. W. (2009). Research design qualitative, quantitative, and mix methods approaches (Third, pp. 1-251). Los Angeles.

Garnida, D. (2015). Pengantar pendidikan inklusif(1st ed.). Bandung: PT Refika Aditama.

Hasanah, U. (2015). Konsep gurunya manusia dalam perspektif munif chatib, 1, 52-63.

Ilahi, M. T. (2013). Pendidikan inklusif: konsep dan aplikasi (1st ed.). Yogyakarta: Ar-Ruzz Media.

Mahabbati, A. (2010). Pendidikan inklusif untuk anak dengan gangguan emosi dan perilaku (tunalaras). Jurnal Pendidikan Khusus, 7(2), 52-63.

Majid, A. (2016). Strategi pembelajaran (5th ed.). Bandung: PT Remaja Rosdakarya.

Mangunsong, F. (2009). Psikologi dan pendidikan anak berkebutuhan khusus (1st ed.). Depok: LPSP3 UI.

Marti, A. D. (2012). Pendidikan inklusif di sekolah dasar kota padang. Jurnal Ilmiah Pendidikan Khusus, $1(3), 1-13$.

Marzano, R. J., \& Marzano, J. S. (2003). The key to classroom management, 61(1), 6-13.

Mcduffie, K. A., Landrum, T. J., \& Gelman, J. A. (2008). Co-teaching and students with emotional and behavioral disorders, 11-17.

Ormrod, J. E. (2009). Psikologi pendidikan membantu siswa tumbuh dan berkembang (6th ed.). Jakarta: Penerbit Erlangga.

Pradnyawati, D., \& Ardjana, I. G. A. E. (2015). Gangguan tingkah laku pada anak. Jurnal Ilmiah Kedokteran, 46(2), 119-125.

Sanjaya, H. W. (2006). Strategi pembelajaran berorientasi standar proses pendidikan (1st ed.). Jakarta: Prenadamedia Group.

Santrock, J. W. (2011). Educational psychology (5th ed.). New York: McGraw-Hill.

Somantri, T. S. (2012). Psikologi anak luar biasa (4th ed.). Bandung: PT Refika Aditama.

Surna, I. N., \& Pandeirot, O. D. (2014). Psikologi pendidikan 1. Jakarta: Penerbit Erlangga.

Sutherland, K. S., Lewis-palmer, T., Stichter, J., \& Morgan, P. L. (2008). Examining the influence of 
Website : http://ejournal.umm.ac.id/index.php/ipa | E-mail : jpa@umm.ac.id

Jurnal Perempuan dan Anak (JPA), Vol. 1 No. 1, Februari 2021, pp. 15-24

ISSN: 2442-2614 print | 2716-3253 online

Universitas Muhammadiyah Malang

teacher behavior and classroom context on the behavioral and academic outcomes for students with emotional or behavioral disorders. The Journal of Special Education, 41(4), 223-233. https://doi.org/10.1177/0022466907310372

Thompson, J. (2010). Memahami anak berkebutuhan khusus. PT Gelora Aksara Pratama.

Williams, J. P. (2014). Nonparticipant observation, (September). 